\title{
ОБРАЗ-СИМВОЛ «ВОДА» В МЕНТАЛЬНОСТІ, КУЛЬТУРІ ТА ЕТИЦ УКРАЇНСЬКОГО НАРОДУ
}

Стрікаленко Т. В., доктор медичних наук, професор, Одеська національна академія харчових технологій, м. Одеса, Украӥна

\section{DOI: https://doi.org/10.31435/rsglobal_conf/25022021/7421}

Abstract. The article analyzes the features in mentality, culture and ethics of the Ukrainian people in theirs attitude to image-symbol of "water". Opoetization of water, of the water world is some kind of narodnopoetichesky dominant which is shown in folklore, the art word. Opoetization of water often defines outlook of Ukrainians, gets into national consciousness, speaks about valid and her even solemn perception. The respect of water and its mystified image can be tracked in all components of spiritual culture of Ukrainians: in folklore, ceremonial songs, Christmas carols, etc. It is proved that such relation has historical roots, but today it is necessary to create new ethics of relationship of the person and water. It is of great importance taking into account new relationship of the person with the nature in general. This relationship demands new responsibility of the person to the nature, new culture of the relations of the person with water and its sources, new ethics of relationship of the person and water.

Keywords: image-symbol "water", mentality, culture, ethics, new ethics

Вступ. Символ води амбівалентний: це джерело родючих сил природи, незамінний харчовий продукт і грізна, руйнівна сила, що несе загрозу для людини і пов'язується зі смертю. Існує і поділ води на «живу» (тала вода, джерельна, дощова) та «мертву» (стояча вода, солона, підземна вода) - у віруваннях, зокрема, давніх слов'ян, у міфології, фольклорі та релігії котрих вода має містичну силу $[3,4,11,13]$.

Дуалістичною цілісністю несвідомого і надсвідомого, ірраціонального і розумового, почуттів і волі вирізняється і духовний світ українства - так вважають дослідники ментальності українського народу М. Попович, С. Кримський, Н. Соболєва, Н. Злобіна, В. Храмова, О. Забужко, М. Шлямкевич, В. Дорошенко, С. Білокінь, Я. Ярема, В. Янів та інші. Загалом, поняття «ментальність», шо увійшло у науковий обіг з 1958 р. завдяки двом французьким дослідникам Ж. Люб’є і Р. Мандру, орієнтує на певну поведінку, цінності і носить світогляднопрактичний характер. Спільним моментом поглядів вітчизняних вчених $є$ акцентування зв'язку поняття ментальність із поняттям душі народу та ії складовими: психічними характеристиками, волею, розумом [23].

Як така, ментальність стоїть в одному ряду з феноменами, що репрезентують етику, духовність і дух особистісного та суспільного життя людини, отже, відповідно до своєї природи, ментальність пронизує всі різновиди й форми існування національного соціуму, $є$ невід'ємною частиною його змісту. Національний характер найповніше відображається саме в культурі, в інтелекті нації, i, зрештою, будь-які елементи людської поведінки функціонують в суспільстві як культурні акти, в контексті національного соціального дискурсу $[3,6,8]$. Адже культура починається і продовжує існувати як продовження природи, що представляє особливий, навіть невідомий самій природі образ, у якому поєднуються природні компоненти 3 їх надприродними смислами, що їх формує культура [10]

Культурно-історичні формоутворення української національної ментальності безпосередньо або опосередковано знаходять проявлення та відображення у будь-яких сферах суспільного життя [7]. Зокрема, на думку Н. Коломінського і А. Льовочкіна, «український менталітет - це результат відображення специфіки взаємодії українців 3 природними та геокліматичними умовами існування і співіснування, що склалися історично» [9].

Найбільш відомою роботою, що визначила воду як чинник впливу на розвиток і прогрес людства, $є$ дослідження Л. І. Мечникова «Цивилизация и великие исторические реки» [12].

Метою нашої роботи було аналітичне обгрунтування розуміння значення образу «вода» в ментальності, культурі та етиці українського народу з поглядів історії та сьогодення. 
Результати дослідження. Вода у всесвіті - це першооснова життя і його принципи виповнені такої колосальної і величної сили, що вона просто не могла не стати символом всього святого для людей різних вірувань і переконань. Фалес Мілетський засади всіх істот бачив у воді: «все з'являється із води і у воді все розпадається... Кожна істота має у воді засади буття і плодючості...» [20, 22].

Арістотель вважав, що основу всього сущого складають вода, повітря, земля та вогонь. «У самих різних міфологіях вода - першоджерело, вихідний стан усього сущого, еквівалент первісного хаосу... Вода - це середовище, агент і принцип загального започаткування i породження...» [13].

Образ води є одним із всезагальних і найдавніших релігійних символів: у біблійній традиції вода $\epsilon$ безоднею і життям водночас, адже з самому початку Дух святий ширяє над водою, перетворюючи хаос на космос. Вода, по суті, передує створенню світу, і вже з води 3'являється низка земних творінь. У самій Біблії слово “вода" зустрічається 284 рази (3 них 232 рази у Старому Заповіті і 52 - у Новому), тоді як назва жодного іншого мінералу, навіть землі, зустрічається менше. Бог утотожнюється із джерелом: «Мене, джерело води живої, залишили... Вода жива $є$ краплею вчення Христова... Вода жива, благодать $є$ Духа Святого...». $[11,15]$. “Якщо хтось не народиться від води і Духа, не зможе увійти в Царство Небесне", - попереджав учнів Ісус Христос.

Вода як першооснова життя і його принцип виповнена такої колосальної сили, що вона просто не могла не стати величним символом святого для людей різних вірувань і переконань $[3,4,8,21]$. «Воді дано таємничу владу бути соком життя на землі» - саме так вважав великий Леонардо да Вінчі [8].

Культ води не змогла знищити жодна релігійна революція, а єдиний ангел природних стихій, що згадується в Біблії - це ангел води [8]. Вода і вогонь були для наших предків святими. I найдавніші шляхи, якими користувались люди, були водяні. Для українців, як зауважує В. Супруненко, найперше значення мав Дніпро-Борисфен, “бо мережею своїх приток обгортав мало не цілу Україну і злучував усі українські землі в одну цілість" [7].

3 великою пошаною джерело води - криниці - оспівано у піснях, опоетизовано у прислів'ях, возвеличено у народних легендах. Як зазначає дослідник В. Скуратівський, 3 давніх-давен у багатьох народів з особливою ретельністю охороняли і прикрашали ці джерела, вважаючи їх святими місцями. Здавна в народі кажуть: яка криниця - такий і господар. Символом низки народних свят, зокрема Івана Купала, було очищення водою і вогнем [16].

Вода - це символ мужності, волі, чистоти, цнотливості, цілющої сили, але водночас жорстокості та невблаганності. Епітети поруч з іменником “вода" викликають ефект високої оцінки, а широке використання слова-символу “вода” у звертаннях набуває пестливого позначення людини, засвідчує їх песоніфікаційні можливості й пріоритети [4]. Не дивно, що вода має чи не найбільше символічних значень: «вода - життя», «вода - межа між світами і станами буття», «вода - жінка», «вода - смерть», «вода - жива вода», «вода - справедливість» [17].

В історії людства, зокрема, в історії українського фольклору, української літератури $\epsilon$ дуже багато пісень, які пов'язані з водою - це говорить про те, що наш народ у своїй ментальності, у своїй підсвідомості завжди пов'язував свій добробут і взагалі виживання саме 3 водою. Календарні (обрядові) пісні, високохудожні твори та їх образи, поетичні засоби створювались протягом багатьох століть - це стосується впливу образу «води» на культуру нашого народу $[3,15,23]$. Адже вода містить у собі «життєве коло і символізує нескінченність буття, оскільки проникає у всі життєві сфери» [5].

Опоетизація води, водного світу становить свого роду народнопоетичну домінанту, що виявляє себе у фольклорі, художньому слові, зрештою визначає світогляд українців, проникає у народну свідомість, визначає шанобливе, часом піднесене урочисте їі сприймання $[15,16,21]$.

Особливістю української ментальності $€$ те, що вона історично і культурно розвивалась як наслідок найрізноманітніших, різнобічних за суттю та проявами національних архетипів, що відтворюють своєрідність ментальних рис української національної культури. Ментальність орієнтує людей на певну поведінку, на певні цінності та етичні норми і носить практичний характер світогляду $[6,8]$.

Проте, може виникнути питання: чи можна аналізувати взаємозв'язок води, матеріального об'єкту, з етикою - однією із форм суспільної свідомості, системою норм моральності людини? Відповідь на це запитання може полягати, по-перше, у самому 
визначенні ментальності: основою національної ментальності є духовна культура народу, мова, фольклор, звичаї, традиції, література, мистецтво, релігія, філософія. Поважне ставлення до води та ії містифікованого образу відслідковується в усіх названих складових духовної культури українців (фольклор, обрядові пісні та колядки тощо) [1].

Разом з цим, сьогодні слід говорити і про етику взаємовідносин людини і води в умовах зміни характеру людської діяльності та повсякденному втручанні іiї з порушенням рівноваги у природі в цілому. Етика своїм предметом має саме відповідальну діяльність, відповідальність. До нашого часу предметом відповідальності людини природа не була, вона сама турбувалась про себе і про людину, тому що нівелювала (утилізувала) «плоди» його діяльності. А людина не створювала проблем довгострокового порушення цілісності природи. Тобто етика відтворювала, в основному, безпосередню взаємодію людини з людиною, тоді як вплив на об'єкти поза діяльністю людини мав, скоріше, віртуальний характер (релігійний, філософський, мистецький тощо) [18].

На разі, дефіцит прісної води сьогодні маємо не лише в окремих країнах, а на планеті в цілому. I це стосується не лише якісної питної води (у тому числі - для нашого якісного харчування), але й усіх прісних вод, так необхідних для життя - для сільськогосподарського виробництва, промисловості тощо. Щодня від вживання недоброякісної води помирає близько 10000 людей [2, 14].

Невиконання основних положень Конвенції $\mathrm{OOH}$ «Про право на воду» свідчить про неблагополуччя «культурного» аспекту управління водними ресурсами (не тільки в країнах Африки, але й в Європі, в Україні), про важливість і необхідність нової етики взаємовідносин людини 3 водою. Етика таких відносин має бути співвідносною 3 етичними проблемами науково-технічного прогресу і володіти даром передбачення ступеню нової відповідальності людини перед водою/природою. водними ресурсами.

Сьогодні прогресує етап «техногенної цивілізації», коли критерій відповідальності «перед водою» - відповідальності у технічних рішеннях, засобах оцінки їх ефективності, методах оцінки якості води в цілому - майже нівельовано [19]. I лише людина, як творець i виконавець науково-технічних досягнень сьогодення, здатна відновити систему норм моральності і етики, що були притаманні людству у нашій історії. Адже культура починається i продовжує існувати як продовження природи, як образ, у якому поєднуються природні компоненти з їх надприродними смислами, що їх формує культура [10].

Висновки. В роботі проаналізовано розуміння значення образу-символу «води»у у ментальності, культурі та етиці українського народу. Опоетизація води, водного світу становить свого роду народнопоетичну домінанту, яка виявляє себе у фольклорі, художньому слові, зрештою визначає світогляд українців і шанобливе, часом піднесене урочисте іiі сприйняття. Поважне ставлення до води та її містифікованого образу відслідковується в усіх складових духовної культури українців.

Показано, що значення цього образу-символу має історичні коріння, проте сьогодні потрібно створювати нову етику відносин людини і води - це має важливе значення з огляду на нові взаємовідносини людини і природи в цілому і потребує нової відповідальності людини перед водою (у часі та просторі). Зрештою - потребує нової культури відносин людей з водою тому, що культура починається і продовжує існувати як продовження природи, як образ, у якому поєднуються природні компоненти з їх надприродними смислами, що їх формує культура.

\section{REFERENCES}

1. Jerome Delli Priscoli, James Dooge, Ramyn Llamas (2004) Overview. Water and Ethics. / World Commission on the Ethics of Scientific Knowledge and Technology UNESCO International Hydrological Programme. Essay №1 - №12. Paris: UNESCO [in English]

2. Water for People, Water for Life (2002). The United Nations World Water Development. Report. (WWDR). Paris: UNESCO-WWAP. 336 p. [in English]

3. Bondarenko O. (2008) Ukrainska-mentalnist v rozmaitti nacionalnih-mentalnih formoutvoren i arhetipiv: istoriko-kulturnij aspekt. Gumanitarnij visnik ZDIA. Vipusk 32. P.66-78. [in Ukrainian].

4. Vardzelashvili Zh, Cerodze C. (2009) Voda kak obraz yazykovoj kartiny mira. Nacionalno-kulturnyj komponent v tekste I yazyke materialy 4 mezhdunar-nauch-konf. Minsk, 3-5 dek 2009 g. V-2-ch. Ch.1. Minsk: MGLU. P.39-41. [in Russian].

5. Vivat G. (2014) Semantika hudozhnih simvoliv u poetichnomu prostori Vasilya Stusa. Odesa. FOP Bondarenko. 264 p. [in Ukrainian]. 
6. Yemelyanova I. (2014) Socialno-istorichni aspekti formuvannya ukrainskoi mentalnosti. Naukovi praci Mikolaivskogo derzhavnogo agrarnogo universitetu. Tom 84. Sociologiya. Vipusk 71. P.58-62. [in Ukrainian].

7. Istoriya ukrainskoi kulturi. (1994) Za red. I. Kripyakevicha. K. Libid. 656 p. [in Ukrainian].

8. Kadirov A. (2003) Voda I ehtika. Razdumya specialista I cheloveka. Tashkent. 108 p. [in Russian].

9. Kolominskij N., Lovochkina A. (2000) Etnopsihologiya ukrainciv. Ukraina na zlami tisyacholit: istorichnij ekskurs, problemi, tendencii ta perspektivi. Za zag. Red. G. Shchokina, M. Golovatogo. K. MAUP. 384 p. [in Ukrainian].

10. Krasnoyarova N. (2006) Priroda kak koncept kultury opyt kulturofilosofskogo ocherka reki vody potoka Elektron. Nauch. zhurnal Vestnik Omskogo ped. in-ta. Vypusk 15. URL: http://www.omsk. edu/article/vestnik-omgpu-15.pdf [in Russian].

11. Kultura I pobut naselennya Ukraini. (1993) Navch. Posib. V. Naulko ta in. 2-ge vid. Doch ta pererob. KLibid. 288 p. [in Ukrainian].

12. Mechnikov L. (2013) Civilizaciya i velikie istoricheskie reki. M.: Ajris-press. 320 p. [in Russian].

13. Mify narodov mira. Enciklopediya (1991) V 2 t. M. T 1. P. 240. [in Russian].

14. Prave na vodu. Osnovnye principy globalnoj ramochnoj Konvencii OON. (2004) Informacionnyj byulleten AVT. Vypusk 8. Odessa: AVT. P.32-39. [in Russian].

15. Prihodchenko K. (2011) Cinnist obrazu-simvolu "voda" v ukrainskij kulturi. Aktualni problemi slovyanskoi filologii Vipusk XXIV, chastina 2. P.265-274. [in Ukrainian].

16. Skurativskij V. (1994) Svyatvechir. Monografiya. V 2 kn. K.: Perlina. 288 p. [in Ukrainian].

17. Sirko I. (2002) Sumvolika v ukrainskiy narodniy baladi. Autoref. kand. dis. 18 p. [in Ukrainian].

18. Strikalenko T. (2006) Voda I ehtika. Voda I vodoochistnye tekhnologii. 3 (19). P. 33-37. [in Russian].

19. Strikalenko T. (2020) Kult vodi v Ukraini: maibutne potrebue minulogo. Gustativno-saporistichn modusi ukrainskoi ta svitovoi kulturi. Kolekt. Monogr. (na materiali II Vseukrainskoi naukovo-teoretichnoi konferents "Kharchovi tradits mentalnii kod natsii"). Za zagalnoiu redaktsii prof G. Vivat. Odesa: FOP Bondarenko. P.124-133. [in Ukrainian].

20. Taranov P. (1996) Anatomiya mudrosti. 120 filosofov. T. 1. Simferopol: Tavriya. [in Russian].

21. Ukrainske narodoznavstvo. (1994) Navch. Posib. Za red S.P. Pavliuka. Lviv: Feniks. 608 p. [in Ukrainian].

22. Fragmenty rannih grecheskih filosofov. (1989) Ch. 1. Ot ehpicheskih teokosmogonij do vozniknoveniyaatomistiki. M. 109 p. [in Russian].

23. Shevel A. (2012) Mentalnist ukraintsiv kriz prizmu prirodi. Naukovi pratsi Glukhivskogo natsionalnogo pedagogichnogo universitetu im. Oleksandra Dovzhenka. Politologiia. Vipusk 192. Tom 204. P. 83-86. [in Ukrainian]. 